\title{
PENINGKATAN KOMPETENSI SISWA DALAM MENYIAPKAN DAN MENYAJIKAN MINUMAN NONALKOHOL MELALUI METODE DEMONSTRASI
}

\author{
Handartiningsih \\ SMKN 2 Godean \\ Handartiningsih@yahoo.com \\ Siti Hamidah \\ Universitas Negeri Yogyakarta \\ Hamidah_66@yahoo.com
}

\begin{abstract}
Abstrak
Penelitian ini bertujuan untuk meningkatkan kompetensi siswa dalam menyiapkan dan menyajikan minuman nonalkohol di SMK Negeri 2 Godean melalui metode demonstrasi secara kolaborasi dengan tenaga ahli dari dunia industri. Penelitian tindakan kelas ini melalui tiga siklus, dimana setiap siklus terdiri dari tiga tahapan yaitu:(1) tahap perencanaan, (2) tahap pelaksanaan pembelajaran dan pengamatan, dan (3) tahap evaluasi dan refleksi. Subjek penelitian adalah siswa SMK Negeri 2 Godean kelas XII Boga 2 sebanyak 35 orang. Instrumen pengumpulan data adalah lembar observasi dan lembar tes. Teknik pengumpulan data menggunakan metode observasi dan tes tertulis maupun tes kinerja. Data yang diperoleh dianalisis secara deskriptif. Hasil penelitian menunjukkan metode demonstrasi secara kolaborasi dapat meningkatkan kompetensi siswa dalam menyiapkan dan menyajikan minuman nonalkohol.
\end{abstract}

Kata Kunci: kompetensi, metode demonstrasi.

\section{IMPROVING STUDENTS COMPETENCIES IN PREPARING AND SERVING NONALCOHOLIC BEVERAGE THROUGH THE DEMONSTRATION METHOD}

\begin{abstract}
This study aims to improve students' competencies in preparing and serving nonalcoholic beverages through the demonstration method in SMK Negeri 2 Godean. The study was conducted in three cycles, each of which consisted of three phases, namely (1) planning, (2) learning implementation and observation, and (3) evaluation and reflection. The research subjects were Grade XII students of Gastronomy 2 in SMK Negeri 2 Godean with a total of 35 students. The data collection instruments consisted of observation sheets and tests. The data collection techniques included observations and written and performance tests. The data were descriptively analyzed. The results of the study show that the demonstration method with collaboration is capable of improving students' competencies in preparing and serving nonalcoholic beverages.
\end{abstract}

Keywords: competency, demonstration method 


\section{PENDAHULUAN}

Pertumbuhan industri makanan dan minuman memiliki peran yang cukup besar dalam menyediakan makanan dan minuman bagi masyarakat. Makanan dan minuman merupakan kebutuhan primer bagi manusia sehingga sampai kapanpun makanan dan minuman tetap dibutuhkan oleh manusia. Selain itu, seiring dengan berkembangnya pariwisata menyebabkan semakin banyak wisatawan datang ke tempat wisata dan dunia hiburan. Dengan demikian maka perlu juga disediakan fasilitas yang memadai untuk memenuhi kebutuhan para wisatawan. Fasilitas yang dibutuhkan mereka antara lain adalah pelayanan makanan dan minuman.

Salah satu bagian dari pelayanan makanan dan minuman adalah pelayanan minuman nonalkohol. Menurut Wiwoho (2009, p.35), minuman nonalkohol adalah minuman yang tidak mengandung kadar alkohol sama sekali. Minuman ini diklasifikasikan dalam tiga kategori, yaitu: stimulating (tea, coffee), refreshing (natural mineral watter, artificial mineral watter, syrup, squash, crush), dan nourishing (juice, milk, cream, cocoa, chocolate). Pendapat tersebut hampir sama dengan yang dikemukakan Darniaty (2009, p.22), minuman nonalkohol adalah minuman tanpa alkohol, yang terdiri dari minuman panas (tea, coffee), dan minuman dingin (natural mineral watter, artificial mineral watter, juice, squash, crush,syrup, mocktail).

Pada saat ini pelayanan minuman nonalkohol banyak ditemukan di dunia industri. Hal ini disebabkan semakin banyak orang yang menyadari pentingnya kesehatan dan bahaya alkohol terhadap kesehatan. Perkembangan teknologi dan peradaban telah menjadikan minuman yang dulu dinilai hanya sebagai pemuas rasa haus kini berubah sebagai minuman yang berfungsi untuk menjaga kesehatan dan penunjuk status seseorang. Metode baru tentang pengolahan serta pelayanan minuman terus berkembang, sehingga minuman nonalkohol dapat disajikan menyesuaikan keinginan peminatnya dengan cara dan penampilan yang menarik.

Pekerjaan dalam pelayanan minuman nonalkohol bukan lagi sekedar menyeduh teh, menyeduh kopi, dan mencampurkan es dengan bahan minuman kemudian menyajikannya kepada tamu. Pekerjaan di bidang pelayanan minuman nonalkohol memerlukan sejumlah kemampuan yang dibutuhkan dunia industri minuman saat ini, antara lain: (1) membuat garnish dengan atraksi fruit carving dan fruit cutting; (2) membuat aneka minuman teh dengan atraksi menggunakan mudler; (3) membuat aneka minuman kopi dengan atraksi membuat lukisan dari creamer di atas permukaan kopi; (4) membuat minuman dingin dengan atraksi mencampur bahan minuman dengan teknik floating sehingga membentuk lapisan antara bahan yang satu dengan bahan lainnya; (5) juggling pada saat meracik minuman nonalkohol.

Sebagai calon tenaga kerja terampil tingkat menengah, siswa SMK Negeri 2 Godean dituntut memiliki kompetensi yang sesuai kebutuhan kerja saat ini. Arifin (2012, p.92) kompetensi adalah pengetahuan, keterampilan, sikap, dan nilai-nilai yang direfleksikan dalam kebiasaan berfikir dan bertindak.

Matoon \& Moore (2010, p.104) defines
competency as follows: competency com-
prises the specification of knowladge and
skill and the aplication of that knowladge
and skill to standard of performance re-
quired in the work place. Lyle \&. Spencer
(1993, p.9) A competency is an underly-
ing characteristic of an individual that is
causally related to criterion-referenced
effective and/or superior performance in
a job or situation. Criterion-referenced
means that the competency actually pre-
dicts who does something well or poorly,
as measured on a specific criterion or
standard.

Kompetensi menyiapkan dan menyajikan minuman nonalkohol adalah kemampuan dasar yang harus diketahui, dimiliki dan dilakukan siswa dalam menyiapkan dan menyajikan minuman tidak beralkohol. Siswa dianggap kompeten apabila dia memiliki pengetahuan, keterampilan, sikap, dan nilainilai untuk melakukan pekerjaan-pekerjaan dalam menyiapkan dan menyajikan minuman nonalkohol dengan tepat.

Siswa SMKN 2 Godean sudah memiliki beberapa kemampuan yang dibutuhkan dunia 
industri saat ini. Mereka sudah mampu membuat garnish dengan teknik fruit carving dan fruit cutting, membuat minuman teh dengan atraksi menggunakan mudler, membuat kopi dengan membuat lukisan di atas creamer dan membuat minuman campuran dengan teknik floating. Namun, mereka belum memiliki kemampuan juggling pada saat meracik minuman.

Kondisi yang telah diuraikan di atas, mendorong SMK Negeri 2 Godean untuk melakukan upaya perbaikan proses pembelajaran. Upaya yang dapat dilakukan sesuai prinsip-prinsip pendidikan kejuruan menurut pendapat Prosser yang ditulis Wardiman (1998, p.38), antara lain: (1) lingkungan dimana siswa dilatih harus merupakan replika lingkungan dimana nanti bekerja; (2) proses latihan dan tugas-tugas yang dilakukan siswa harus dengan cara dan alat yang sama seperti yang diperlukan dalam pekerjaan itu; (3) guru telah mempunyai pengalaman sukses dalam penerapan kompetensi; (4) kompetensi yang diberikan sesuai permintaan dunia industri; (5) metode pembelajaran yang digunakan mempertimbangkan sifat-sifat peserta didik; dan 6) isi pelatihan dari pengalaman para ahli.

Clarke \& Winch (2007, p.62) menyatakan bahwa "vocational education is about the social development of labour, about nurturing, advancing and reproducting particular qualities of labour to improve the productive capacity of society",

Henry Thompson dalam Berg (2002:p.45) menjelaskan bahwa pendidikan kejuruan itu identik dengan belajar bagaimana bekerja. Vocational education is "learning how to work". Additionally, vocational education is geared on the needs of the job market.

Sunaryo, dkk (2002, p.230 dan p.558). Pendidikan di SMK akan lebih bermakna dan menjadi efektif jika melibatkan pihak dunia industri mulai dari penyusunan program pendidikan, pelaksanaan, evaluasi hingga pemasaran tamatannya Satu aspek penting yang tidak boleh dilupakan SMK adalah relevansi kompetensi yang diberikan kepada siswa dengan tuntutan dunia kerja. Orientasi tersebut membawa konsekuensi bahwa SMK harus bekerjasama dengan dunia industri. Melalui kerjasama yang kooperatif berarti dunia industri terkait ikut merasa memiliki dan mendukung pendidikan di SMK. Bentuk dukungan dunia industri yang dibutuhkan SMK diantaranya adalah: (1) memberi masukan untuk pengembangan kurikulum dan bahan ajar yang sesuai dengan tuntutan dunia kerja; (2) memberikan fasilitas praktik; (3) penyelenggaraan magang bagi siswa maupun guru; (4) rekruitmen tenaga kerja tamatan SMK; dan (5) menugaskan staf yang ahli pada kompetensi tertentu (tenaga ahli) untuk mengajar atau menjadi nara sumber dalam pembelajaran di sekolah.

Kenyataannya, pembelajaran menyiapkan dan menyajikan minuman nonalkohol di SMKN 2 Godean belum sepenuhnya berdasar pada kebutuhan dunia kerja saat ini. Berbagai perubahan yang terjadi menyebabkan sekolah belum dapat menekankan pada penguasaan kompetensi yang dibutuhkan dunia industri saat ini. Proses pembelajaran pun belum pernah berkolaborasi dengan dunia industri dan belum menerapkan metode demonstrasi secara optimal.

Upaya yang dilakukan SMK Negeri 2 Godean adalah membentuk tim yang terdiri dari guru di sekolah dan tenaga ahli dari dunia industri. Proses pembelajaran teori dan praktik kejuruan dapat dilakukan secara kolaborasi antara guru dan tenaga ahli. Pembelajaran dasar yang diberikan guru di sekolah dapat dilengkapi dengan ketrampilan khusus juggling yang diberikan tenaga ahli dari dunia industri. Guru dan tenaga ahli yang berkolaborasi menggunakan berbagai metode pembelajaran dengan menekankan pada penggunaan metode demonstrasi.

Metode demonstrasi adalah metode mengajar dengan cara memperagakan barang, kejadian, aturan dan urutan melakukan suatu kegiatan, baik secara langsung maupun melalui penggunaan media pengajaran yang relevan dengan pokok bahasan atau materi yang sedang disajikan (Mushibbin Syah, 2008, p.208).

The demonstration is the basic method for introducing new skills to the learner. It consists of nothing more than showing the learner how the new skills should be performed. The showing is done by the teacher while the learner observes. The 
showing is accompanied by explanation on the part of the teacher of the 'how' of the skills being demonstrated. As simple as this appears to be, it can easily fall short of its purpose unless the following suggestions are observed (Leighbody \& Kidd, 1968, p. 41).

Sintaks atau langkah-langkah metode demonstrasi yang harus diterapkan dalam proses pembelajaran menurut panda[at Gintings (2010, p.54) adalah: (1) merumuskan dengan jelas kecakapan atau keterampilan apa yang akan diperoleh setelah demonstrasi dilakukan; (2) tentukan peralatan yang digunakan, kemudian dicoba dahulu agar pelaksanaan demonstrasi tidak mengalami keg agalan; (3) menetapkan prosedur yang dilakukan, dan sebelum demonstrasi dilakukan perlu diadakan percobaan terlebih dahulu; (4) menentukan lama pelaksanaan demonstrasi; (5) memberikan kesempatan kepada siswa untuk berkomentar; (6) meminta kepada siswa untuk mencatat hal-hal yang dianggap perlu; dan (7) menetapkan rencana untuk menilai kemajuan siswa.

Pendapat di atas dapat dinyatakan bahwa metode demonstrasi adalah cara yang dilakukan guru dalam membimbing siswa melakukan suatu pekerjaan dengan memperagakan langkah-langkah kegiatan yang sesungguhnya, kemudian siswa diberi kesempatan melakukan latihan seperti yang diperagakan guru. Metode demonstrasi secara kolaborasi antara guru dengan tenaga ahli dari dunia industri dilakukan dilakukan dengan cara menunjukkan gerakan juggling kepada siswa disertai dengan penjelasan bagaimana seharusnya keterampilan juggling pada saat meracik minuman nonalkohol itu dilakukan. Siswa mengamati dengan seksama dan menirukannya.

Pembelajaran dengan metode demonstrasi di SMK Negeri 2 Godean menitik beratkan pada penguasaan pengetahuan dan keterampilan spesifik serta sikap yang sesuai dengan apa yang harus dilakukan dan diterapkan di dunia kerja. Pengetahuan dan keterampilan tersebut harus dapat didemonstrasikan siswa sesuai standar kompetensi yang berlaku.

Berdasarkan latar belakang tersebut, SMK Negeri 2 Godean melakukan penelitian tin- dakan kelas (PTK). Tujuan penelitian adalah meningkatkan kompetensi siswa dalam menyiapkan dan menyajikan minuman nonalkohol. Masalah dalam penelitian ini dibatasi pada bagaimana meningkatkan kompetensi siswa kelas XII Boga-2 SMK Negeri 2 Godean. Hasil penelitian ini diharapkan dapat memberikan informasi tentang upaya peningkatan kompetensi siswa dalam menyiapkan dan menyajikan minuman nonalkohol melalui metode demonstrasi yang dilakukan secara kolaborasi antara guru dan tenaga ahli.

\section{METODE PENELITIAN}

\section{Jenis Penelitian}

Jenis penelitian yang digunakan dalam penelitian ini adalah Classroom Action Research (CAR), dalam bahasa Indonesia dikenal dengan Penelitian Tindakan Kelas (PTK). Desain penelitian yang dipilih adalah desain PTK model Piggot-Irvine. Model penelitian ini menggambarkan proses penelitian tindakan berbentuk spiral yang mengarah ke atas memperagakan langkah-langkah perencanaan (Plan), pengambilan tindakan (Act) dan refleksi (Reflect). Langkah pengamatan dilaksanakan bersamaan dengan langkah pelaksanaan tindakan karena pengamatan terhadap tindakan tidak mungkin dilakukan tanpa ada pelaksanaan tindakan. Evaluasi untuk mengetahui berhasil tidaknya tindakan ini dilaksanakan pada saat refleksi.

Desain penelitian model Piggot-Irvine dapat dilihat pada gambar 1 .

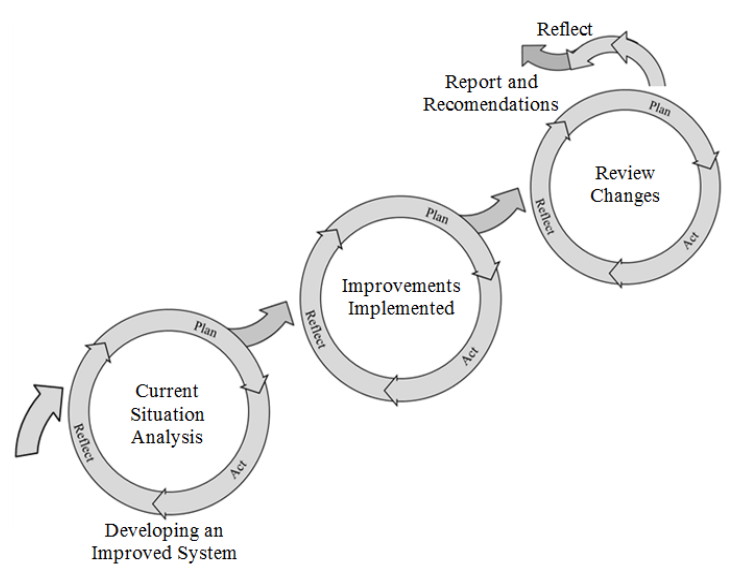

Gambar 1. Desain Penelitian Tindakan Model Piggot-Irvine 
Kriteria keberhasilan yang digunakan dalam penelitian ini adalah tercapainya minimal $85 \%$ dari jumlah siswa yang kompeten dalam melakukan minimal lima macam gerakan juggling yang bervariasi pada saat menyiapkan dan menyajikan minuman nonalkohol secara efektif dengan cara yang menarik dan mendapat nilai rata-rata minimal 80. Jika belum tercapai $85 \%$ dari jumlah siswa yang dinyatakan kompeten dan mendapat nilai minimal 80, maka siklus dilanjutkan. Namun, jika sudah tercapai $85 \%$ dari jumlah siswa yang dinyatakan kompeten dan mendapat nilai minimal 80, maka siklus dihentikan.

\section{Waktu dan Tempat Penelitian}

Penelitian dilakukan di SMKN2 Godean, Jalan Jae Sumantoro, Sidoagung, Godean pada semester ganjil tahun ajaran 2013/2014.

\section{Subjek Penelitian}

Subjek penelitian ini adalah siswa kelas XII Boga-2 bidang studi tata boga kompetensi keahlian Jasa Boga di SMK Negeri 2 Godean, dengan jumlah 35 orang. Dari tiga kelas paralel yang ada, peneliti memilih kelas XII Boga-2 sebagai subyek penelitian karena kelas ini merupakan kelas yang memiliki rata-rata terendah dalam kompetensi menyiapkan dan menyajikan minuman nonalkohol.

\section{Prosedur}

Tindakan dilaksanakan berdasarkan alur penelitian tindakan kelas (PTK). Secara keseluruhan, pelaksanaan tindakan dilakukan dalam 3 tahapan yaitu (1) tahap perencanaan; (2) tahap pelaksanaan tindakan; dan pengamatan, dan (3) tahap evaluasi dan refleksi.

\section{Data, Instrumen dan Teknik Pengumpulan Data}

Pengumpulan data dilakukan melalui tes dan observasi. Hasil tes digunakan untuk memantau peningkatan kompetensi siswa. Tes yang dilakukan disini berupa tes tertulis dan unjuk kerja yang dilaksanakan pada setiap siklusnya. Tes unjuk kerja digunakan dengan mengacu pada suatu standar yang ingin dicapai sebagai batas minimum yang harus bisa dilakukan oleh siswa. Penilaian unjuk kerja dilakukan karena pelajaran kompetensi menyiapkan dan menyajikan minuman nonalkohol adalah pelajaran praktik sehingga penilaian yang paling sesuai adalah penilaian proses. Nilai unjuk kerja/praktik diambil dengan pengamatan yaitu dengan metode observasi terstruktur tentang apa yang akan diamati.

Validitas instrumen penelitian dilakukan dengan cara uji validitas isi (content validity) dengan meminta pendapat para ahli (expert judgment). Instrumen yang digunakan dalam pengumpulan data untuk mengukur aspek kognitif adalah tes tertulis bentuk soal pilihan ganda dan bentuk soal uraian. Lembar observasi digunakan untuk mengukur aspek afektif. Lembar observasi disusun dengan model skala pengukuran dengan empat alternatif. Lembar penilaian praktik digunakan untuk mengukur aspek psikomotor. Aspek yang diukur dalam domain psikomotor pada penelitian ini adalah kinerja siswa dalam melakukan juggling pada saat meracik minuman nonalkohol. Untuk mengukurnya, guru menggunakan pedoman penilaian atau rubrik yang sudah disiapkan sebelumnya. Guru memberikan nilai dan mencatatnya pada lembar penilaian sesuai kriteria yang telah ditentukan dalam pedoman penilaian. Untuk skor kurang dari 8,0 dinyatakan belum kompeten dan skor diatas 8,0 dinyatakan kompeten. Nilai ditentukan dengan cara membagi jumlah skor yang diperoleh dengan jumlah skor maksimal, kemudian dikalikan 100 . Bobot nilai aspek psikomotor pada penelitian tindakan ini adalah 50\%.

Nilai kompetensi siswa dalam menyiapkan dan menyajikan minuman nonalkohol ditentukan dengan cara menjumlahkan nilai ketiga aspek, yaitu dengan cara menghitung nilai aspek kognitif dengan bobot $30 \%$, nilai aspek afektif dengan bobot $20 \%$ dan nilai aspek psikomotor dengan bobot $50 \%$, kemudian menjumlahkan hasil perhitungan ketiga aspek tersebut.

\section{Teknik Analisis Data}

Data hasil belajar diambil dari hasil observasi terstruktur berupa data kuantitatif kemudian dikonversi menjadi data kualitatif. Data yang diperoleh dibandingkan/dikonversikan dengan standar acuan untuk menentukan kompetensi siswa dalam kategori tertentu. Nilai akhir yang diperoleh dikonversi menggunakan 
skala lima dengan penilaian yang terentang dari sangat baik sampai tidak baik (buruk). Berikut ini standar acuan skala lima menurut pendapat Arifin (2012, p.234):

Tabel 1. Standar Acuan

\begin{tabular}{cc}
\hline Tingkat Penguasaan & Kategori \\
\hline $90-100$ & Sangat baik \\
$80-89$ & Baik \\
$70-79$ & Cukup baik \\
$60-69$ & Kurang baik \\
$\leq 59$ & Tidak baik \\
\hline
\end{tabular}

Setelah data dikumpulkan, data dianalisa dengan deskriptif kualitatif. Hasil analisa tersebut ditelaah dan dipelajari, kemudian dirangkum. Hasil rangkuman tersebut kemudian dikembangkan menjadi paparan yang mendalam berdasarkan pemahaman peneliti. Peneliti akan mengkaji kepustakaan, dan mengkonfirmasi temuan dengan teori yang sudah ada sebelumnya.

\section{HASIL PENELITIAN DAN PEMBAHASAN}

SMK Negeri 2 Godean memperbaiki proses pembelajaran kompetensi menyiapkan dan menyajikan minuman nonalkohol. Pihak sekolah mengembangkan kerjasama dengan dunia industri. Salah satu pola kerjasama yang dilakukan adalah membentuk tim yang terdiri dari guru di sekolah dan tenaga ahli dari dunia industri. Pembelajaran teori dan praktik dasar kejuruan yang diberikan guru di sekolah dilengkapi dengan ketrampilan khusus juggling yang diberikan tenaga ahli. Guru dan tenaga ahli membimbing dengan memperlihatkan langkah-langkah proses menyiapkan dan menyajikan minuman nonalkohol dengan mendemonstrasikan penggunaan alat atau melaksanakan kegiatan tertentu seperti kegiatan yang sesungguhnya. Guru melibatkan tenaga ahli dalam pembelajaran. Hal ini sesuai pendapat (Yamin,2010, p.65), bahwa metode demonstrasi dapat diterapkan dengan syarat memiliki keahlian.

Kolaborasi ini telah menghasilkan manfaat yang signifikan untuk siswa, yaitu: (1) siswa dapat memperoleh gambaran nyata kom- petensi yang relevan dengan kebutuhan dunia kerja; (2) terjadi perubahan perilaku yang meliputi pengetahuan, keterampilan, dan sikap yang terkait dengan pekerjaan menyiapkan dan menyajikan minuman nonalkohol; (3) terjadi penularan profesionalisme dari tenaga ahli kepada siswa melalui metode demonstrasi oleh tenaga ahli; (4) dapat mengurangi kesalahankesalahan yang terjadi bila dibandingkan dengan hanya membaca, mendengarkan atau melihat di internet; (5) memperjelas persoalan yang selama ini menimbulkan pertanyaan atau keraguan pada diri siswa; (6) siswa dapat menguasai keterampilan juggling dengan lebih mudah dan sistematis. Hal ini sesuai dengan pendapat Djamarah (2008, p.211),

\section{Aspek Kognitif}

Pembelajaran teori pada siklus I disampaikan menggunakan media power point yang ditayangkan melalui LCD. Materi yang diberikan berupa pengetahuan yang relevan dengan pekerjaan di dunia industri. Materi dirumuskan secara bersama-sama dengan tenaga ahli dari dunia industri.

Perhatian siswa dalam kegiatan pembelajaran pada siklus I belum dapat dipusatkan pada hal-hal yang dianggap penting. Beberapa siswa terlihat kurang antusias mengikuti pelajaran teori. Setelah dilaksanakan proses refleksi pada akhir siklus I dan dilaksanakan perbaikan pada siklus II, perhatian siswa dalam kegiatan pembelajaran teori meningkat. Perbaikan yang dilakukan adalah menayangkan DVD tentang materi menyiapkan dan menyajikan minuman nonalkohol yang disampaikan oleh tenaga ahli. Hasil belajar aspek kognitif pada siklus I mencapai 88,57\%. Setelah dilakukan perbaikan pada siklus II, hasil belajar aspek kognitif mencapai 91,43\%. Pencapaian hasil belajar aspek kognitif pada siklus II mengalami peningkatan. Namun ada 5 (lima) siswa yang nilainya menurun.

Siswa mengakui bahwa menurunnya nilai karena mereka tidak memahami beberapa bagian materi. Ketidakpahaman mereka disebabkan oleh suara DVD yang kurang jelas didengar bagi mereka. Menurunnya nilai juga karena mereka tidak mengira akan diadakan tes tertulis lagi setelah diadakan tes pada siklus 
I. Mereka merasa tidak siap mengerjakan tes tertulis yang diberikan guru tanpa pemberitahuan sebelumnya.

Hasil penelitian ini sesuai hukum kesiapan (The Law Readiness) tentang adanya hubungan antara kesiapan seseorang dalam merespon stimulan yang diberikan (Gintings, 2010, p.19). Pemberian tes tertulis yang diberikan kepada siswa tanpa pemberitahuan lebih dulu menyebabkan mereka tidak siap untuk melakukannya. Siswa tidak dapat mengerjakan tes tersebut dengan baik sehingga hasilnya kurang memuaskan dan dapat menimbulkan kekecewaan dalam diri siswa.

Setelah dilaksanakan proses refleksi pada akhir siklus II dan dilaksanakan perbaikan pada siklus III, perhatian siswa dalam kegiatan pembelajaran teori meningkat. Perbaikan yang dilakukan adalah menayangkan DVD tentang materi menyiapkan dan menyajikan minuman nonalkohol dilengkapi sound system.Perhatian dan antusias siswa meningkat karena gambar dan suara penjelasan pada tayangan DVD dapat diterima dengan jelas. Hasil belajar aspek kognitif pada siklus III mengalami peningkatan mencapai 94,29\%. Berikut ini peningkatan hasil belajar pada aspek kognitif.

Tabel 2. Peningkatan Hasil Belajar Kognitif

Peningkatan Hasil Belajar Aspek Kognitif

\begin{tabular}{lll}
\hline Siklus I & $88,57 \%$ & Baik \\
Siklus II & $91,43 \%$ & Sangat Baik \\
Siklus III & $94,29 \%$ & Sangat Baik \\
\hline
\end{tabular}

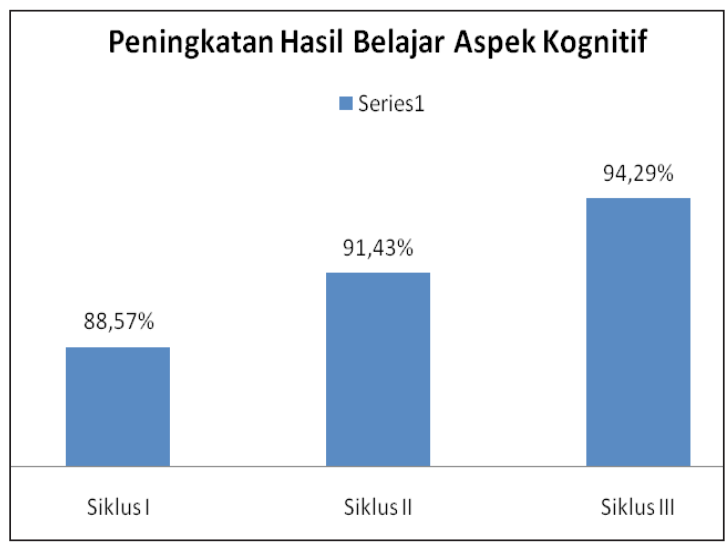

Gambar 2. Grafik Peningkatan Hasil Belajar Kognitif.

\section{Aspek Afektif}

Indikator aspek afektif yang diamati dalam penelitian ini adalah (1) sikap ramah, (2) disiplin, (3) menghargai orang lain, (4) komitmen, dan (5) tanggung jawab pada saat menyajikan minuman sesuai standar dan waktu yang ditentukan. Kelima indikator tersebut dianggap penting karena sangat terkait dengan kompetensi siswa dalam menyiapkan dan menyajikan minuman nonalkohol. Siswa perlu memiliki kompetensi tersebut.

Hasil penelitian menunjukkan bahwa kemampuan afektif siswa meningkat. Hal-hal yang dianggap penting dan perlu diperhatikan selama menyajikan minuman kepada tamu dapat dicermati dengan lebih jelas. Siswa dapat melayani teman dan guru yang berperan sebagai tamu dengan sikap yang lebih baik. Peningkatan hasil belajar aspek afektif dapat dilihat pada tabel 3 .

Hasil tindakan yang terlihat pada gambar 3 telah menunjukkan bahwa kemampuan afektif siswa meningkat setelah dilakukan upaya memperbaiki proses pembelajaran. Guru mengubah strategi pembelajaran, penggunaan media, suasana kelas, dan materi pelajaran menjadi lebih baik dan menyenangkan bagi siswa. Peningkatans kemampuan afektif siswa dapat diketahui dari tingkah laku yang menunjukkan adanya kesenangan belajar.Kekurangankekurangan yang terjadi selama proses pembelajaran diperbaiki pada proses pembelajaran berikutnya agar lebih baik dan menyenangkan bagi siswa yang belajar.Hasil penelitian ini sesuai dengan pendapat Darmiyati (2010, p.28) bahwa kemampuan afektif siswa dapat dipengaruhi oleh faktor yang terkait dengan suasana sekolah seperti guru, suasana kelas, materi kurikulum, dan strategi instruksional.

\section{Aspek Psikomotor}

Salah satu indikator aspek psikomotor pada kompetensi menyiapkan dan menyajikan minuman nonalkohol adalah menyajikan minuman secara efektif dengan cara yang menarik. Salah satu kemampuan yang diperlukan pada saat menyajikan minuman nonalkohol adalah juggling. Pencapaian setiap indikator pada kompetensi juggling dianggap penting sehingga perlu upaya agar siswa memiliki 
Tabel 3. Peningkatan Hasil Belajar Aspek Afektif

\begin{tabular}{lccc}
\hline Indikator & Siklus I & Siklus II & Siklus III \\
\hline Bersikap Ramah & $86 \%$ & $88 \%$ & $93 \%$ \\
Disiplin & $85 \%$ & $89 \%$ & $91 \%$ \\
Menghargai Orang lain & $87 \%$ & $88 \%$ & $90 \%$ \\
Komitmen & $91 \%$ & $91 \%$ & $93 \%$ \\
Tanggung Jawab & $80 \%$ & $82 \%$ & $89 \%$ \\
\hline
\end{tabular}

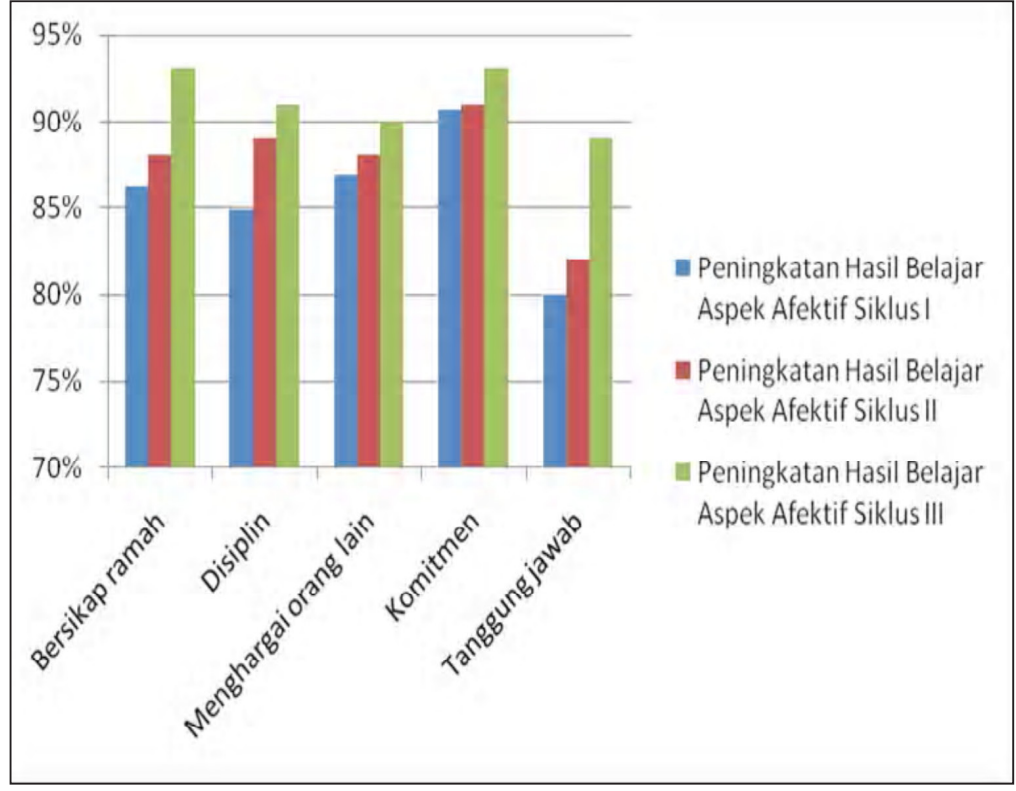

Gambar 3. Grafik Peningkatan Hasil Belajar Afektif

kompetensi tersebut. Semua indikator aspek psikomotor juggling yang diamati pada penelitian ini dirumuskan oleh tenaga ahli dan guru. Untuk memperoleh data tentang pencapaian hasil belajar aspek psikomotor, guru membuat alat pengukuran berupa tes kinerja.

Selama kegiatan praktik berlangsung, guru dan kolaborator melakukan pengamatan dan memberikan penilaian terhadap aspek apsikomotor dengan menggunakan pedoman penilaian yang sudah disiapkan. Setelah dilaksanakan proses refleksi pada setiap akhir siklus dan dilaksanakan perbaikan pada siklus berikutnya, perhatian pada kegiatan pembelajaran praktik dan hasil belajar siswa meningkat. Peningkatan hasil belajar pada aspek psikomotor dapat di lihat pada tabel 4.

Dengan menganalisa hasil belajar dan hasil evaluasi pembelajaran, upaya perbaikan dilakukan dengan memperbaiki bagian-bagian yang dipandang masih belum baik. Kekurangan-kekurangan yang terjadi selama proses pembelajaran diperbaiki pada proses pembelajaran berikutnya. Perbaikan yang dilakukan adalah: (1) mengubah strategi penggunaan media power point dengan DVD; (2) peragaan lebih banyak dilakukan dalam kelompok yang kecil agar semua siswa mendapat kesempatan maksimal; (3) memberikan bimbingan khusus kepada siswa yang mengalami kesulitan belajar; (4) DVD demonstrasi ditayangkan dengan kecepatan diperlambat dan diputar secara berulang-ulang; (5) peralatan yang digunakan untuk juggling dengan bentuk dan ukuran standar; (6) menggunakan DVD yang dilengkapi sound system sebagai pengeras suara; (7) siswa melakukan praktik juggling sambil meracik minuman dengan bahan minuman sebenarnya, dan (8) menyiapkan musik untuk mengiringi juggling.

Perhatian siswa dalam kegiatan pembelajaran sudah dapat lebih dipusatkan pada hal-hal yang dianggap penting. Siswa sangat antusias mengikuti pelajaran praktik. Guru membimb- 
Tabel 4. Peningkatan Hasil Belajar Aspek Psikomotor

\begin{tabular}{llccc}
\hline $\begin{array}{l}\text { No } \\
\text { Soal }\end{array}$ & \multicolumn{1}{c}{ Indikator } & Siklus I & Siklus II & Siklus III \\
\hline 1 & Mengambil dan memegang botol dengan benar & $100 \%$ & $100 \%$ & $100 \%$ \\
2 & Melempar dan menangkap botol dalam keadaan berdiri & $91 \%$ & $100 \%$ & $100 \%$ \\
3 & Membawa botol di telapak tangan tanpa berjalan & $100 \%$ & $100 \%$ & $100 \%$ \\
4 & Membawa botol di telapak sambil berjalan & $86 \%$ & $97 \%$ & $100 \%$ \\
5 & Melempar dan menangkap dengan punggung tangan & $37 \%$ & $89 \%$ & $94 \%$ \\
6 & Membawa botol di punggung tangan tanpa berjalan & $77 \%$ & $100 \%$ & $100 \%$ \\
7 & Membawa botol di punggung tangan sambil berjalan & $69 \%$ & $100 \%$ & $100 \%$ \\
8 & Melempar botol dan menggenggam badan botol & $86 \%$ & $100 \%$ & $100 \%$ \\
9 & Menuangkan cairan ke dalam gelas lalu memutar botol & $83 \%$ & $100 \%$ & $100 \%$ \\
10 & Melempar dan menangkap shaker di tempat & $83 \%$ & $100 \%$ & $100 \%$ \\
11 & Melempar dan menangkap shaker sambil memutar botol. & $66 \%$ & $100 \%$ & $100 \%$ \\
12 & Melempar dan menangkap botol dengan shaker & $34 \%$ & $86 \%$ & $91 \%$ \\
13 & Memutar botol sambil melempar shaker ke arah belakang & $74 \%$ & $100 \%$ & $100 \%$ \\
14 & Menuangkan ke dalam shaker melingkar di punggung & $40 \%$ & $89 \%$ & $94 \%$ \\
15 & Memasang mixing glass pada shaker. & $94 \%$ & $100 \%$ & $100 \%$ \\
\hline
\end{tabular}

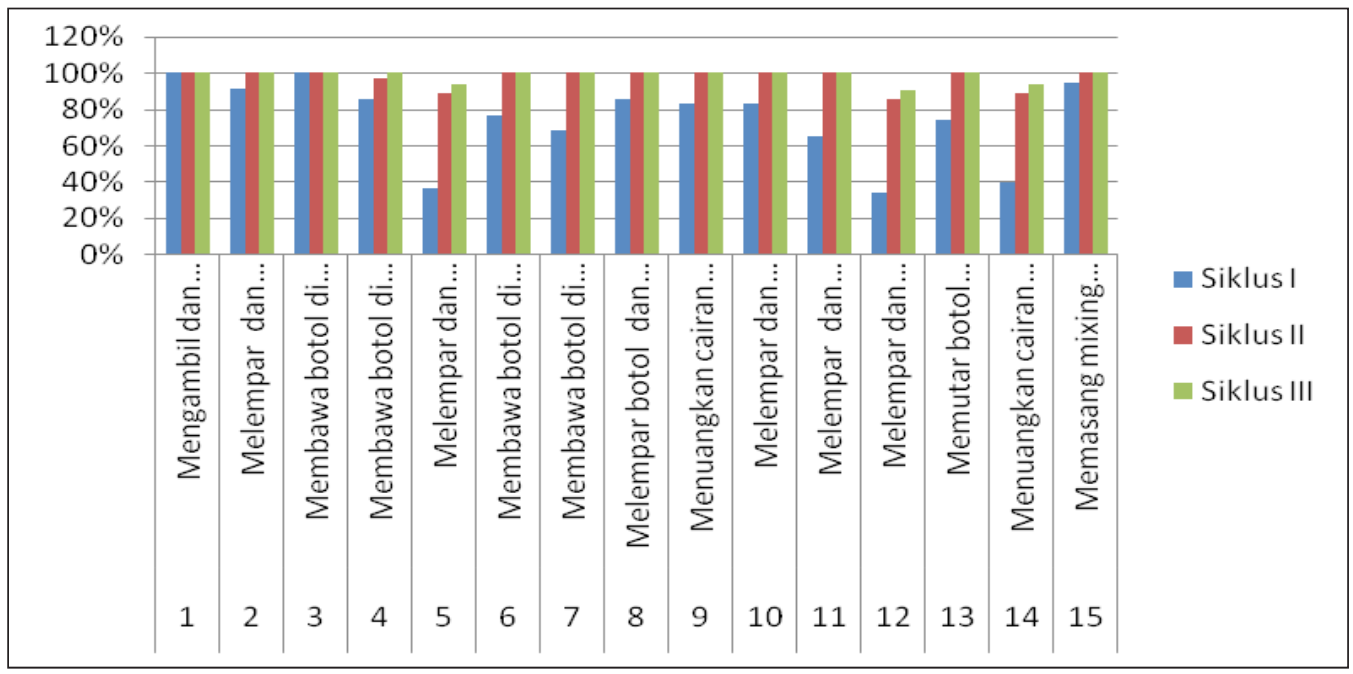

Gambar 4. Grafik Peningkatan Hasil Belajar Aspek Psikomotor

ing siswa yang belum mampu menguasai juggling dengan menayangkan peragaan juggling secara berulang-ulang. Dengan menggunakan botol imitasi yang standar, siswa lebih mudah melakukan gerakan juggling. Siswa lebih mahir melakukan juggling dengan kombinasi gerakan yang lebih variatif. Siswa juga dapat melakukan juggling sambil meracik minuman dengan alat dan bahan sebenarnya dengan diiringi musik. Berikut ini peningkatan kompe- tensi siswa dalam menyiapkan dan menyajikan minuman nonalkohol

Perbaikan proses pembelajaran di kelas XII Boga-2 SMK Negeri 2 Godean telah meningkatkan hasil belajar dan kompetensi siswa dalam menyiapkan dan menyajikan minuman nonalkohol. Kondisi ini menunjukkan bahwa pembelajaran lebih bermakna dan menjadi efektif dengan melibatkan pihak dunia industri mulai dari penyusunan program pendidikan, 
Tabel 5. Peningkatan Rata-rata Nilai Akhir Kompetensi

\begin{tabular}{lccc}
\hline & \multicolumn{3}{c}{ Peningkatan Rata-Rata Nilai Akhir } \\
Tindakan & Rata-rata Kognitif & Rata-rata Afektif & Rata-rata Psikomotor \\
Siklus I & 81 & 86 & 77 \\
Siklus II & 83 & 88 & 81 \\
Siklus III & 90 & 91 & 82 \\
\hline
\end{tabular}

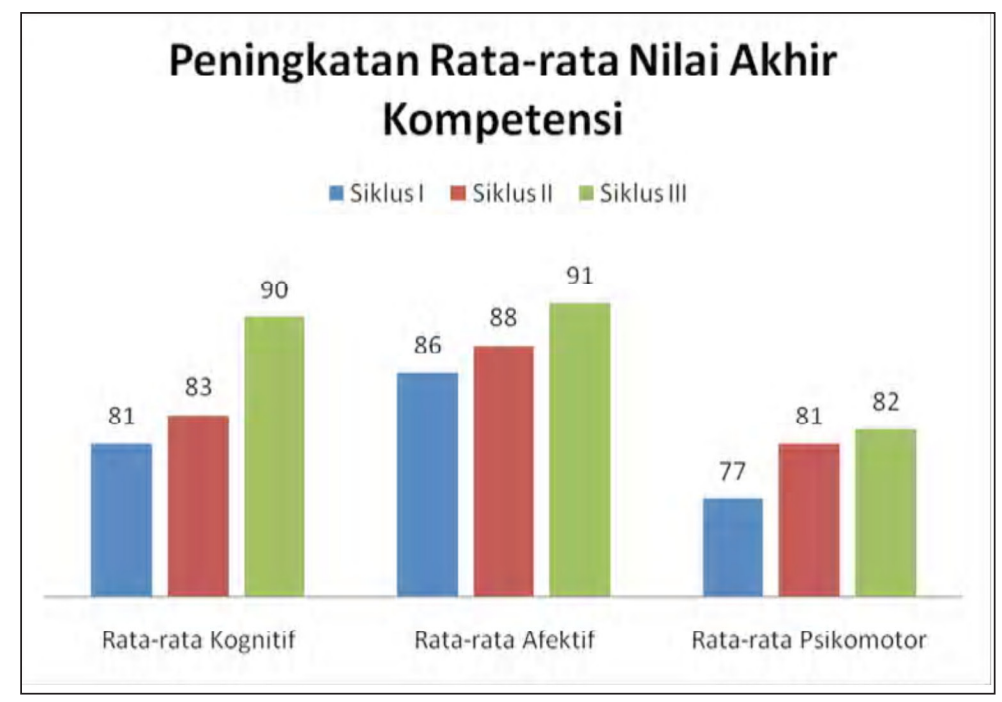

Gambar 5. Grafik Peningkatan Rata-rata Perolehan Nilai Akhir

pelaksanaan, dan evaluasi. Kompetensi yang diberikan kepada siswa juga lebih relevan dengan tuntutan dunia kerja. Kompetensi yang diberikan kepada siswa kelas XII SMK Negeri 2 Godean lebih sesuai dengan tuntutan dunia kerja karena tenaga ahli dari dunia industri lebih mengerti tentang kompetensi yang relevan dengan dunia kerja. Melalui kerjasama yang kooperatif ini, dunia industri telah memberikan dukungan yang dibutuhkan, diantaranya adalah: (1) memberi masukan untuk pengembangan bahan ajar yang sesuai dengan tuntutan dunia kerja; (2) memberikan fasilitas praktik dengan meminjamkan alat yang sesuai standar; dan (3) menugaskan staf yang ahli untuk mengajar atau menjadi nara sumber dalam pembelajaran menyiapkan dan menyajikan minuman nonalkohol di sekolah.Hasil penelitian ini sesuai pendapat (Sunaryo dkk, 2002, p.230 dan p.588).

Guru dan tenaga ahli selalu berupaya mengarahkan perhatian dan membangkitkan motivasi siswa dalam proses pembelajaran agar tujuan pembelajaran dapat tercapai. Upaya yang dilakukan guru antara lain: (1) menggunakan multimedia (visual dan audio visual), dan multimetode (ceramah, tanya jawab, demonstrasi); (2) memberi tugas kepada siswa untuk membaca, menulis, melihat, menirukan dan sebagainya; (3) membimbing siswa untuk terlibat dan mengalami langsung proses belajar dengan melakukan praktik gerakan juggling dan meracik minuman nonalkohol; (4) memberikan tugas dan meminta siswa untuk melakukan latihan-latihan yang dikerjakan secara berulang sehingga berbagai daya dapat berkembang dengan baik dan siswa semakin terbiasa melakukannya.

Kompetensi menyajikan minuman secara efektif dengan cara yang menarik memberi tantangan kepada siswa untuk mampu melakukan juggling pada saat meracik minuman nonalkohol. Selain itu, penilaian tertulis dan kinerja juga memberikan tantangan bagi siswa untuk belajar lebih giat dan sungguhsungguh. Hasil belajar yang baik merupakan balikan yang menyenangkan dan memperkuat antusias belajar siswa dan hasil belajar yang tidak menyenangkan dapat dijadikan balikan bagi siswa untuk meningkatkan kegiatan bela- 
jar selanjutnya. Dengan demikian siswa lebih antusias mengikuti pembelajaran. Hal ini dilakukan sesuai pendapat Dimyati dan Mudjiono yang dikutip Arifin (2012, p.294) bahwa keberhasilan pembelajaran akan tercapai jika guru melaksanakan pembelajaran dengan berpijak pada prinsip-prinsip pembelajaran, yaitu perhatian dan motivasi, keaktifan, keterlibatan langsung, pengulangan, tantangan, balikan dan penguatan, dan perbedaan individual.

Langkah-langkah dalam penerapan metode demonstrasi diperhatikan dengan cermat mulai dari perencanaan, pelaksanaan, dan evaluasi. Berikut ini adalah kunci keberhasilan penerapan metode demonstrasi yang dilakukan guru dan tenaga ahli: (a) Waktu persiapan dan pelaksanaan yang cukup dan sesuai rencana. Hal ini disebabkan guru mempelajari terlebih dahulu materi yang akan diajarkan dan merencanakan kegiatan pembelajaran sesuai waktu yang tersedia secara cermat; (b) Peralatan yang digunakan sudah standar karena sekolah memfasilitasi botol sebenarnya dan botol imitasi untuk juggling dengan bentuk dan ukuran standar; (c) Peragaan dapat dilakukan secara berulang-ulang dengan kecepatan yang disesuaikan kebutuhan siswa.; (d) Guru membimbing siswa dalam kelompok kecil sehingga semua siswa mendapat kesempatan berlatih secara berulang ulang. Siswa semakin terbiasa dan lebih mahir.

Metode demonstrasi dalam penelitian tindakan ini berhasil meningkatkan kompetensi siswa dalam menyiapkan dan menyajikan minuman nonalkohol karena: (1) guru melakukan persiapan dengan baik; (2) menggunakan peralatan yang dapat didemonstrasikan dan dapat diamati dengan seksama oleh siswa; (3) peragaan dilakukan guru dan tenaga ahli secara berulang-ulang dan dalam kelompok yang kecil sehingga semua siswa mendapat kesempatan; (4) semua siswa melihat atau mengamati keseluruhan peristiwa yang didemonstrasikan; dan (5) guru menggunakan ruang aula karena tidak semua hal dapat didemonstrasikan di ruang kelas. Hal ini sesuai pendapat Gintings (2010: p.54), Yamin (2010, p.66) dan Djamarah (2008, p.211).

Proses pembelajaran di SMK Negeri 2 Godean dengan membimbing siswa melalui peragaan suatu pekerjaan dengan langkah- langkah kegiatan sesungguhnya, menggunakan alat dan bahan sesuai standar sebenarnya, kemudian siswa diberi kesempatan melakukan latihan seperti yang diperagakan guru secara berulang-ulang telah membuat siswa semakin terbiasa melakukannya. Kebiasaan tersebut semakin melekat pada diri siswa sehingga keterampilan yang dimiliki menjadi suatu pekerjaan yang dapat dilakukannya secara otomatis. Hal ini sesuai pendapat Leighbody \& Kidd (1968, p.41).

\section{SIMPULAN DAN SARAN}

\section{Simpulan}

Berdasarkan hasil penelitian tindakan kelas yang dilakukan di kelas XII Boga-2 SMK Negeri 2 Godean, maka dapat ditarik kesimpulan sebagai berikut: (1) Metode demonstrasi dapat meningkatkan kemampuan siswa pada aspek kognitif; (2) Metode demonstrasi dapat meningkatkan kemampuan siswa pada aspek afektif; (3) Metode demonstrasi dapat meningkatkan kemampuan siswa pada aspek psikomotor.

Dengan demikian dapat dinyatakan bahwa proses pembelajaran dengan menerapkan metode demonstrasi secara kolaborasi antara guru dengan tenaga ahli dapat meningkatkan kompetensi siswa kelas XII Boga-2 SMK Negeri 2 Godean dalam menyiapkan dan menyajikan minuman nonalkohol.

\section{Saran}

Sebaiknya guru menerapkan metode demonstrasi secara optimal dengan melakukan uji coba serta penyempurnaan skenario peragaan yang akan didemonstrasikan. Langkahlangkah yang diperagakan harus dapat diamati dengan seksama agar siswa tidak melakukan kesalahan dalam menirukan langkah-langkah kunci yang didemonstrasikan. Guru harus memberi kesempatan kepada siswa untuk menirukan gerakan yang didemonstrasikan secara berulang-ulang agar siswa terbiasa melakukan pekerjaannya dengan benar.

Bagi sekolah, sebaiknya mendukung penerapan metode demonstrasi dengan cara memfasilitasi alat yang standar, perlengkapan yang mendukung, media yang tepat dan 
ruangan yang sesuai kebutuhan. Sekolah juga perlu meningkatkan keahlian guru sesuai bidangnya agar metode demonstrasi yang diterapkan dalam pembelajaran lebih optimal. Namun, jika sekolah belum mampu melengkapi fasilitas yang diperlukan, maka sekolah dapat melibatkan pihak dunia usaha/industri untuk berperan serta dalam proses pembelajaran. Dunia industri dapat berperan serta secara aktif dengan memberikan fasilitas praktik dan menugaskan tenaga ahli untuk mengajar dengan menerapkan metode demonstrasi secara kolaborasi antara guru dengan tenaga ahli dari dunia industri.

\section{DAFTAR PUSTAKA}

Arifin, Zainal.(2012). Evaluasi Pembelajaran. Bandung: Remaja Rosdakarya

Bahri, Syaiful (2008). Konsep dan makna pembelajaran. Jakarta: Alfabeta

Berg, G.A. (2002). Why distance learning? Higher education administrative practices. New York: Praeger Publisher.

Clarke, L. \& Winch C. (2007). International approaches, Developments and systems. Madison Avenue, New York: Routledge.

Darniaty. (2009). Melayani makan dan minum. Depok: Pusat pengembangan penataran guru kejuruan bidang bisnis dan pariwisata.
Djojonegoro, Wardiman. (1998). Pengembangan Sumberdaya Manusia. Jakarta: Jayakarta Agung

Gintings, Abdorrakhman. (2010). Belajar dan pembelajaran. Bandung: Humaniora

Leighbody \& Kidd, Donal M.. (1968). Methods of teaching shop and technical subjects. New York: Delmar Publisers.

Maton, K \& Moore, R. (2010) Social realism, knowladge and the sociology ofeducation: Coalitions of The Mind. New York: Continum.

Spencer, Lyle M. (1993) Competence at work: models for superior performance. New York: Praeger Publisher.

Sunaryo, dkk (2002). Sejarah pendidikan teknik dan kejuruan di Indonesia, membangun manusia produktif. Jakarta: Direktorat Pendidikan Menengah Kejuruan Departemen Pendidikan Nasional RI.

Wiwoho, Ardjuno. (2009). Pengetahuan minuman dan bartending. Jakarta: Erlangga

Yamin, Martinis. (2010). Strategi pembelajaran berbasis kompetensi. Jakarta: Gaung Persada

Zuchdi, Darmiyati. (2008). Humanisasi pendidikan. Jakarta: Bumi Aksara 